Article

\title{
Sewage Sludge Treatment by Hydrothermal Carbonization: Feasibility Study for Sustainable Nutrient Recovery and Fuel Production
}

\author{
Gabriel Gerner ${ }^{1, *}$, Luca Meyer ${ }^{1}$, Rahel Wanner ${ }^{1}$, Thomas Keller ${ }^{2}\left(\mathbb{D}\right.$ and Rolf Krebs ${ }^{1}(\mathbb{D}$ \\ 1 Institute of Natural Resource Sciences, Campus Grüental, Zurich University of Applied Sciences (ZHAW), \\ CH-8820 Wädenswil, Switzerland; luca.meyer@zhaw.ch (L.M.); rahel.wanner@zhaw.ch (R.W.); \\ rolf.krebs@zhaw.ch (R.K.) \\ 2 Institute of Chemistry and Biotechnology, Campus Reidbach, Zurich University of Applied Sciences (ZHAW), \\ CH-8820 Wädenswil, Switzerland; thomas.keller2@zhaw.ch \\ * Correspondence: gabriel.gerner@zhaw.ch; Tel.: +41-58-934-5588
}

Citation: Gerner, G.; Meyer, L.; Wanner, R.; Keller, T.; Krebs, R. Sewage Sludge Treatment by Hydrothermal Carbonization: Feasibility Study for Sustainable Nutrient Recovery and Fuel Production. Energies 2021, 14, 2697. https://doi.org/10.3390/en14092697

Academic Editor: M. Toufiq Reza

Received: 10 March 2021

Accepted: 30 April 2021

Published: 8 May 2021

Publisher's Note: MDPI stays neutral with regard to jurisdictional claims in published maps and institutional affiliations.

Copyright: (C) 2021 by the authors. Licensee MDPI, Basel, Switzerland. This article is an open access article distributed under the terms and conditions of the Creative Commons Attribution (CC BY) license (https:/ / creativecommons.org/licenses/by/ $4.0 /)$.

\begin{abstract}
Phosphorus recovery from waste biomass is becoming increasingly important, given that phosphorus is an exhaustible non-renewable resource. For the recovery of plant nutrients and production of climate-neutral fuel from wet waste streams, hydrothermal carbonization (HTC) has been suggested as a promising technology. In this study, digested sewage sludge (DSS) was used as waste material for phosphorus and nitrogen recovery. HTC was conducted at $20{ }^{\circ} \mathrm{C}$ for $4 \mathrm{~h}$, followed by phosphorus stripping (PS) or leaching (PL) at room temperature. The results showed that for PS and PL around $84 \%$ and $71 \%$ of phosphorus, as well as $53 \%$ and $54 \%$ of nitrogen, respectively, could be recovered in the liquid phase (process water and/or extract). Heavy metals were mainly transferred to the hydrochar and only $<1 \mathrm{ppm}$ of $\mathrm{Cd}$ and $21-43 \mathrm{ppm}$ of $\mathrm{Zn}$ were found to be in the liquid phase of the acid treatments. According to the economic feasibility calculation, the HTC-treatment per dry ton DSS with an industrial-scale plant would cost around 608 USD. Between $349-406 \mathrm{~kg}$ of sulfuric acid are required per dry ton DSS to achieve a high yield in phosphorus recovery, which causes additional costs of 96-118 USD. Compared to current sewage sludge treatment costs in Switzerland, which range between 669 USD and 1173 USD, HTC can be an economically feasible process for DSS treatment and nutrient recovery.
\end{abstract}

Keywords: hydrothermal carbonization; phosphorus recovery; digested sewage sludge; hydrochar; nutrient recovery; climate-neutral fuel; energy efficiency; economic feasibility

\section{Introduction}

To meet global food demand, the utilization of mineral fertilizer in agriculture has become indispensable. While the production of phosphorus $(\mathrm{P})$ and nitrogen $(\mathrm{N})$ fertilizer cause a negative environmental impact, phosphate rock is also a limited resource and since 2014 it has been on the list of Critical Raw Materials for the European Union (EU) [1,2]. Phosphorus as an essential plant nutrient represents a considerable environmental burden due to its production from phosphate ores. According to Binder et al. [3] and Daneshgar et al. [4], easily accessible phosphorus will only last for the next 300 years, while we could reach the phosphorus peak already by 2070 [5]. In addition to huge mining areas, the production of phosphoric acid from phosphate ore leaves behind hundreds of millions of tons of phosphogypsum, some of which is radioactive [6]. Radioactive material such as uranium as well as heavy metals (HM) like cadmium can be transferred from the ore to the mineral P fertilizer [7-12]. A study by the Braunschweig Federal Research Center for Cultivated Plants JKI (Julius Kühn-Institute) found in triple superphosphate 52-232 $\mathrm{mg} / \mathrm{kg}$ of uranium [6]. Recycling of phosphorus from waste streams offers a sustainable alternative to conserve phosphorus deposits and reduce impurities in plant fertilizer. In 
contrast to phosphorus, which relies on a definite source, nitrogen fertilizer can be synthesized as ammonia from air by the Haber-Bosch process [13]. The negative aspect of this process is that to produce ammonia fertilizer, it consumes between 1-2\% of global energy and produces around $1.4 \%$ of global $\mathrm{CO}_{2}$ emissions [14]. Countries like Switzerland and Germany approved new regulations to reduce the dependency on phosphorus imports. It will be mandatory to recycle phosphorus from sewage sludge by 2026 in Switzerland and by 2029 in Germany [15]. This attempt to reduce mismanagement of this exhaustible resource and the need for high-quality fertilizer has increased the necessity of a phosphorus recycling process with high nutrient recovery and low environmental burden. Hydrothermal carbonization (HTC) is a thermochemical process allowing the direct usage of wet feedstock without drying them and converting it under high pressure and temperature to a coal slurry, which can be separated into an energy-rich solid phase (hydrochar) and nutrient-rich liquid phase (process water) [16]. The conversion leads to reduced NO emission in the hydrochar combustion [17] and simultaneously improves dewaterability of the carbonized sludge $[18,19]$, which is crucial for an energy-efficient separation. In this process, phosphorus is mainly incorporated in the hydrochar and has to be removed by acid leaching [20-22]. Other processes use sewage sludge ash for P-leaching [23], where the sludge's fuel property is mainly used as process energy for the incineration. Therefore, it is lost to industrial processes like the cement industry or coal power plants as climate-neutral fuel.

Modern wastewater treatment plants (WWTP) employ biological and/or chemical phosphorus removal technologies to transfer around $90 \%$ of the input phosphorus load into the sewage sludge [24]. Larger WWTPs utilize the sludge as a feedstock for anaerobic digestion (AD) producing methane, which can be converted to electricity and heat to cover energy demands. Implementing an HTC plant on-site allows the methane yield to be increased by feeding the AD with HTC process water (PW), as a supplemental feedstock with high organic carbon content [20,25-30]. Recovered energy can at the same time be utilized for the HTC process and increase the energy efficiency.

Different studies show the potential of P-recovery by applying acids before or after the HTC treatment $[20,22,31,32]$ and the need for using digested sewage sludge. For the acid application, digested sludge has a higher $\mathrm{P}$ availability compared to raw sludge, while with raw sludge only $50 \%$ of $\mathrm{P}$ can be recovered at $\mathrm{pH} 2$ [23]. For a profitable application of the process a cost-effective usage of acid must be achieved.

The aim of this study was to investigate the recovery of plant nutrients (phosphorus and nitrogen) from digested sewage sludge for a sustainable fertilizer and fuel production with the main focus on minimizing the acid usage and increasing the PW utilization. Two paths of P-recovery are investigated in lab-scale experiments, with immediate acid application before and after liquid-solid separation and without prior drying to simulate industrial processing. Process liquids are analyzed for their nutrient and heavy metal content and hydrochars are examined for their fuel properties as possible substitutes for fossil fuels. Furthermore, the economic feasibility of the process in an industrial-scale HTC-plant is evaluated.

\section{Materials and Methods}

\subsection{Digested Sewage Sludge}

For this study anaerobically digested sewage sludge was used as a raw material. The digested sewage sludge (DSS) was collected at a WWTP in Switzerland (ARA Rietliau, Waedenswil, Switzerland), with an initial dry matter content of $22.30 \%$ (dried at $105{ }^{\circ} \mathrm{C}$ ). The WWTP consists of four treatment trains, two with membrane bioreactors (MBR) and microfiltration $(0.35 \mu \mathrm{m}$ pore size) and two with conventional activated sludge (CAS) treatments. It was built for a population equivalent of 44,000 and treats communal and industrial wastewater. For chemical phosphorus precipitation, iron (III) chloride and poly aluminum chloride (PAC) are used by the WWTP. The collected DSS was immediately transferred to a convection oven and dried at $40{ }^{\circ} \mathrm{C}$ for $86 \mathrm{~h}$ (BINDER GmbH, Tuttlingen, 
Germany). The slowly dried stock was homogenized by grinding to a fine powder (GM200, Retsch $\mathrm{GmbH}$, Haan, Germany) and stored in airtight $1 \mathrm{~L}$ glass bottles (DURAN ${ }^{\circledR}$ GLS $80^{\circledR}$ laboratory wide mouth bottle, DURAN Group GmbH, Mainz, Germany) for HTC trials. These sludge pre-treatments are conducted to achieve a better reproducibility of the lab-scale experiments. In large-scale HTC-treatments sewage sludge will be treated directly after dewatering, without previous drying step.

\subsection{Hydrothermal Carbonization}

HTC lab experiments were carried out using a $1 \mathrm{~L}$ pressure vessel made from Hastelloy ${ }^{\circledR}$ $\mathrm{C} 22^{\circledR}$ (Büchi AG, Uster, Switzerland). All trials were run in duplicates. The reactor vessel was loaded with $600 \mathrm{~g}$ of a mixture of dried DSS and deionized (DI) water. The input amount of DSS (dried at $40{ }^{\circ} \mathrm{C}$ ) was adjusted by its remaining moisture content (measured at $105^{\circ} \mathrm{C}$ ) to obtain a final dry matter (DM) content of $20 \%$. The reactor head space contained a small amount of air. Reaction time was set at $4 \mathrm{~h}$ after reaching a reaction temperature of $200{ }^{\circ} \mathrm{C}$. The residence time was selected in accordance with the parameters from the industrial-scale reactor from GRegio Energie AG, Chur, Switzerland. During the reaction a maximum pressure of 18.8 bar $( \pm 0.2)$ was reached. The reactor jacket contained an electric heating mantle and water-cooling coil for short heating and cooling phases. Heating up from room to the set temperature took around $30 \mathrm{~min}$ and the cooling below $50{ }^{\circ} \mathrm{C}$ around $13 \mathrm{~min}$. The mixture was stirred continuously at $200 \mathrm{rpm}$. All trials were monitored in situ for temperature and pressure. The resulting product of HTC is a mixture (HTC-slurry) of a solid (hydrochar) and liquid (process water) fraction. The HTC-slurry was transferred into a $1 \mathrm{~L}$ glass bottle (DURAN ${ }^{\circledR}$ GLS $80^{\circledR}$ laboratory wide mouth bottle) and afterwards vacuum filtered through a Buchner funnel with a Whatman filter paper (pore size $11 \mu \mathrm{m}$, Cat No 1001 125). The PW was stored until analysis at $6{ }^{\circ} \mathrm{C}$ and the hydrochar was, without a washing step, dried at $40^{\circ} \mathrm{C}$ overnight. Dewaterability of the hydrochar was calculated based on the DM content (dried at $105^{\circ} \mathrm{C}$ ), achieved after simple vacuum filtration.

\subsection{Phosphorus Extraction}

Figure 1 shows the flow charts of experimental set-ups with and without acid addition. To optimize the acid dose achieving maximum P recovery by minimizing the PW contamination with acid and heavy metals, the following three experimental set-ups were tested: (i) HTC-C (control): direct liquid-solid separation without any acid addition; (ii) HTC-PS (phosphorus stripping): acid addition to the slurry followed by L/S-separation; and (iii) HTC-PL (phosphorus leaching): Short-time sedimentation of hydrochar particles followed by decantation of surplus process water and acid addition to remaining hydrochar. The last set-up was conducted to reduce the amount of acidified process water, while concentrating the leached nutrients in the extract. Because of the hydrophobic characteristics of the hydrochar [18], the sedimentation took place immediately. Acid extractions (leaching or stripping) were carried out directly after HTC in the $1 \mathrm{~L}$ glass bottle, without any intermediate step. All slurries were stirred continuously at $600 \mathrm{rpm}$ with a magnetic stirrer (Big Squid, IKA, Breisgau, Germany). Initial $\mathrm{pH}$ value was recorded, followed by a stepwise addition of $1 \mathrm{~mL}$ concentrated sulfuric acid (93-98\%, Hiperpur, PanReac AppliChem, Darmstadt, Germany) to the mixture until a $\mathrm{pH}$ of 2 was reached. After reaching the desired $\mathrm{pH}$ value the reaction time of $2 \mathrm{~h}$ started [33]. During the reaction, the glass bottle was covered with aluminum foil to minimize the loss from evaporation and the $\mathrm{pH}$ value was measured every $15 \mathrm{~min}$ and adjusted with $0.5-1 \mathrm{~mL}$ acid addition. After $2 \mathrm{~h}$ the mixture was vacuum filtered through a Buchner funnel with a Whatman filter paper (pore size $11 \mu \mathrm{m}$, Cat No 1001 125). The liquid samples were stored at $6{ }^{\circ} \mathrm{C}$ and hydrochars were, without a washing step, directly transferred to the convection oven and dried at $40^{\circ} \mathrm{C}$ over night. Remaining PW (incl. nutrients) on char was considered as a loss, to keep the treatment for industrial-scale applications simple and cost effective. 

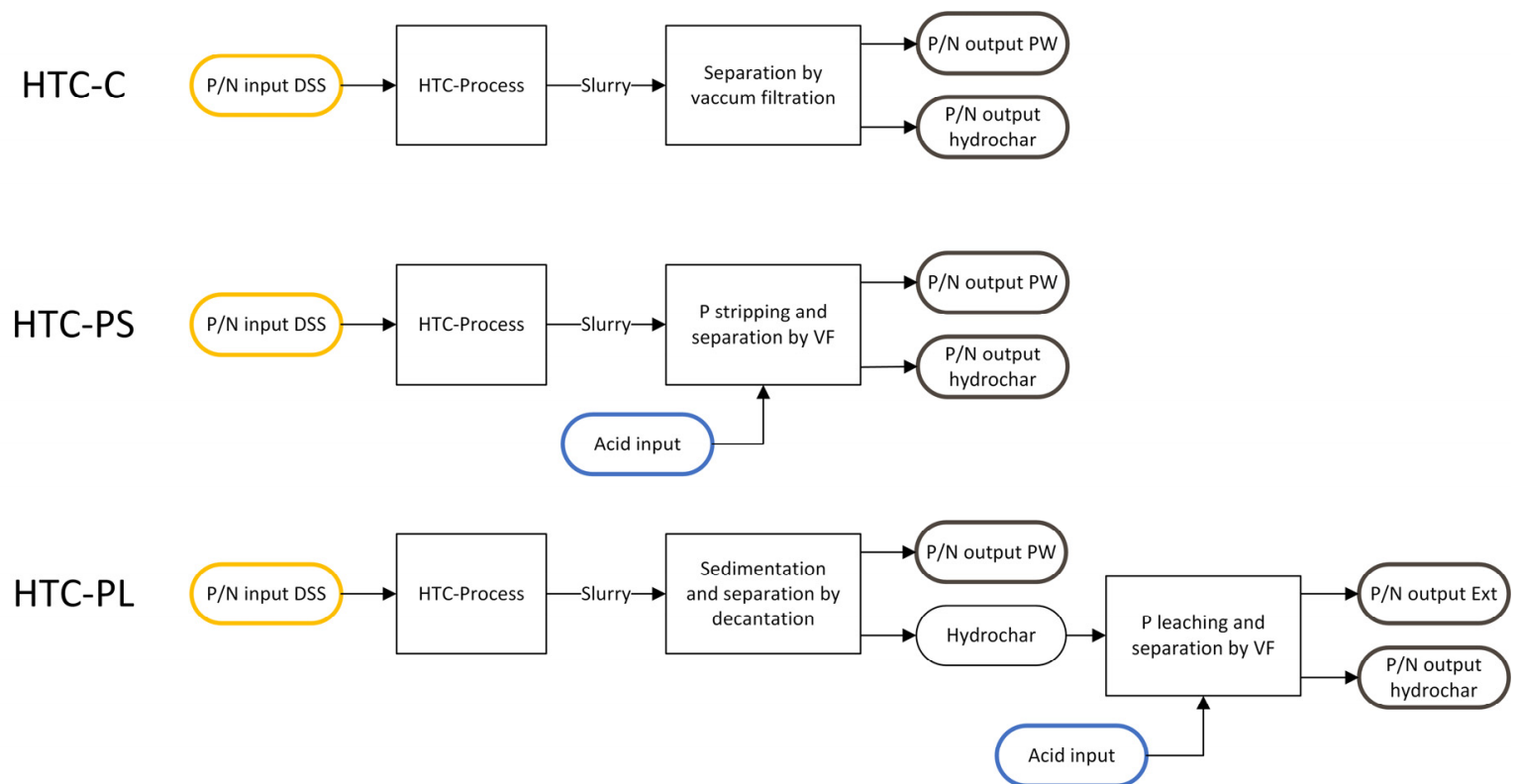

Figure 1. Flow charts of experimental set-ups with and without acid addition. (HTC $=$ Hydrothermal carbonization, $\mathrm{C}=$ Control, PS = P-Stripping, PL = P-Leaching, DSS = Digested sewage sludge, PW = Process water, Ext = Leaching extract, $\mathrm{VF}$ = Vacuum filtration).

\subsection{Characterization of Feedstock and HTC-Products}

DSS and hydrochars were analyzed for DM and ash content. To avoid losses of mercury due to volatilization, all samples were previously dried at $40{ }^{\circ} \mathrm{C}$ [34] for further analyses and the initial DM content $\left(\% \mathrm{DM}_{40 \mathrm{C}}\right)$ was recorded. As a second step, subsamples were taken and dried at $105^{\circ} \mathrm{C}$ until constant weight was reached $\left(\% \mathrm{DM}_{105 \mathrm{C}}\right)$. The effective DM content (\% DM) was then calculated by Equation (1):

$$
\operatorname{DM}(\text { wt. } \%)=\operatorname{DM}_{40 C}(\text { wt. } \%) \times \mathrm{DM}_{105 \mathrm{C}}(\text { wt. } \%) \div 100
$$

After determination of the $\mathrm{DM}_{105 \mathrm{C}}$, samples were incinerated in a muffle furnace (L 40/11 BO, Nabertherm GmbH, Lilienthal, Germany) and the ash content was measured according to DIN EN 14775. Ultimate analyses for carbon $(\mathrm{C})$, hydrogen $(\mathrm{H})$ and $\mathrm{N}$ were undertaken with a CHN-analyzer (TruSpec Macro, LECO Instrumente $\mathrm{GmbH}$, Mönchengladbach Germany) and sulfur was measured at an external lab with a CHNSanalyzer (vario EL cube, Elementar Analysensysteme GmbH, Langenselbold, Germany). All samples for ultimate analyses were dried at $105^{\circ} \mathrm{C}$. Oxygen content was calculated by difference (Equation (2)):

$\mathrm{O}($ wt. $\%)=100-\mathrm{C}($ wt.\% $)-\mathrm{H}($ wt.\% $)-\mathrm{N}($ wt.\%) $-\mathrm{S}($ wt.\%) - Ash content (wt.\%)

Total content of $\mathrm{HM}(\mathrm{Cd}, \mathrm{Cu}, \mathrm{Ni}, \mathrm{Pb}$ and $\mathrm{Zn})$ and phosphorus $(\mathrm{P})$ was measured for liquid and solid samples spectroscopically by ICP-OES (Agilent 5100, Agilent Technologies, CA, USA). $2 \mathrm{~mL}$ of liquid sample or $0.35 \mathrm{~g}$ of solid sample (dried at $40{ }^{\circ} \mathrm{C}$ ) was added to $8 \mathrm{~mL}$ of aqua regia and microwave digested (Speedwave Four, Berghof Products + Instruments $\mathrm{GmbH}$, Eningen, Germany) for $35 \mathrm{~min}$ at $175^{\circ} \mathrm{C}$ (in dependence on SN EN 13346 , protocol C). After the acid digestion samples were transferred to a $25 \mathrm{~mL}$ volumetric flask and diluted with ultrapure water. Final results for solid samples were corrected by the remaining water content $\left(\% \mathrm{DM}_{105 \mathrm{C}}\right)$. Acid digestion using aqua regia did not lead to a complete digestion for solid char samples. Therefore, measurement results were utilized for material balance and recovery efficiency was determined. The results showed good overall recovery with $>83 \%$ for $\mathrm{HM}$ (excl. $\mathrm{Pb}, \mathrm{Cd}$ and $\mathrm{Hg}$ ) and nutrients. Dilution effects in liquid samples faced detection limitations, especially for elements with low 
concentrations as $\mathrm{Pb}, \mathrm{Cd}$ and $\mathrm{Hg}$. Phosphorus contents for hydrochars were calculated by difference. All samples were digested in triplicates and average results are reported. For the determination of mercury $(\mathrm{Hg})$ samples dried at $40^{\circ} \mathrm{C}$ were measured according to DIN EN 1483: 08.97. Mercury was analyzed using a cold vapor atomic absorption spectrometer (CV-AAS) (novAA ${ }^{\circledR} 350$, Analytik Jena $\mathrm{GmbH}$, Jena, Germany) equipped with a hydride generator (HS 60A, Analytik Jena GmbH, Jena, Germany).

Liquid samples (process water and leaching extract) were analyzed for total organic carbon (TOC), measured as non-purgeable organic carbon (NPOC), according to ASTM D7573 and total bound nitrogen (TNb) according to DIN EN 12260 with a TOC- $\mathrm{L}_{\mathrm{CSH}}$ analyzer equipped with a TNM-L unit (Shimadzu, Kyoto, Japan). For TOC measurements the samples were automatically acidified with $\mathrm{HCl}$ to $\mathrm{pH}<3$ and sparged with purified air to remove inorganic carbon. Purgeable organic carbon (POC) may also be lost during this sample treatment. The $\mathrm{pH}$ values of fresh process water and leachate were measured with a portable multi-parameter meter (HQ40d, Hach Lange, Düsseldorf, Germany).

Hydrochars were further characterized for its fuel properties. Regarding energy content, the higher heating value (HHV) of the raw material and the hydrochar was measured using a calorimeter (IKA C 200, Breisgau, Germany). The volumetric emissions of $\mathrm{CO}_{2}$ and $\mathrm{SO}_{2}$ were calculated according to Equations (3) and (4) adapted from Kaltschmitt [35], on the assumption of a complete combustion. Weight percentage of carbon (c) and sulfur (s) are given by the elemental analysis:

$$
\begin{aligned}
& \mathrm{CO}_{2} \text { emission }\left(\frac{\mathrm{m}^{3} \mathrm{CO}_{2}}{\mathrm{~kg} \mathrm{DM}}\right)=22.41 \frac{\mathrm{c}}{12} \\
& \mathrm{SO}_{2} \text { emission }\left(\frac{\mathrm{m}^{3} \mathrm{SO}_{2}}{\mathrm{~kg} \mathrm{DM}}\right)=22.41 \frac{\mathrm{s}}{32}
\end{aligned}
$$

The hydrochar yield and energy efficiency (EE) were calculated by Equations (5) and (6), respectively [36-38].

$$
\begin{gathered}
\text { Hydrochar yield }(\%)=\left(\frac{\mathrm{DM}_{\text {hydrochar }}(\mathrm{kg})}{\mathrm{DM}_{\text {raw material }}(\mathrm{kg})}\right) \times 100 \\
\text { Energy efficiency }(\%)=(\text { Hydrochar yield }) \times\left(\frac{\mathrm{HHV}_{\text {hydrochar }}\left(\frac{\mathrm{MJ}}{\mathrm{kg}}\right)}{\mathrm{HHV}_{\text {raw material }}\left(\frac{\mathrm{MJ}}{\mathrm{kg}}\right)}\right)
\end{gathered}
$$

\subsection{Economic Feasabiliy of Hydrothermal Carbonization (HTC)}

For the economic calculation, on-site treatment at a WWTP with anaerobic sludge digestion was presumed. Therefore, transport and PW treatment costs were neglected. The investment costs and annul fixed costs were obtained by the HTC-company GRegio Energie AG, Switzerland. All Swiss franc (CHF) amounts are reported in US dollars (USD) and were converted at the exchange rate of 1.1 USD/CHF. The costs include the HTC-process, liquid-solid separation with a hydraulic filter press (HPS, Bucher Unipektin AG, Switzerland), as well as drying and briquetting of the hydrochar. Annual fixed costs are based on Swiss rates and include electrical and thermal energy (electricity rate 0.22 $\mathrm{USD} / \mathrm{kWh}$; heating rate $0.066 \mathrm{USD} / \mathrm{kWh})$, rent (198.00 USD $\left./ \mathrm{m}^{2} \mathrm{a}\right)$, labor, maintenance, provision and contingency insurance, as well as capital costs. Labor costs are based on a full time-position. Capital costs were calculated based on a payback period of 10 years with $2 \%$ annual interest. Annual provision and insurance costs are $1 \%$ and maintenance costs are $2.5 \%$ of the investment. Costs for the P-extraction were calculated based on the acid consumption in the lab experiments, and do not include industrial scale plant costs and/or fertilizer production. An average market price of 275 USD per ton of industrial 
grade $\mathrm{H}_{2} \mathrm{SO}_{4} 98 \%$ was applied. Specific overall costs per dry ton DSS were determined by Equation (7).

Specific overall cos ts (CHF per ton DSS $)=\left(\frac{\text { Annual fixed cos ts (CHF per year) }}{\text { Annual troughput (tons per year) }}\right)$

The industrial scale HTC-plant from GRegio Energie AG is operating continuously with a reactor volume of $5.6 \mathrm{~m}^{3}$. The maximum flow rate of the current system is $2 \mathrm{~m}^{3} / \mathrm{h}$ and is limited by the heating system and heat recovery unit. The optimal DM content of the sludge input material is around $15 \%$. For the calculation of the disposal fees the throughput was set at 11,200 tons dewatered sewage sludge (15\%DM) per year. With a carbonization time of $4 \mathrm{~h}$ and a yearly operation time of $8000 \mathrm{~h}$, the flow rate was set to $1.4 \mathrm{~m}^{3} / \mathrm{h}$.

\section{Results and Discussion}

\subsection{Carbonization and Separation}

For the characterization of hydrochars and liquid phases extensive analysis were conducted. Higher heating values of the raw material and hydrochars are shown in Table 1. HTC of DSS causes a slight decrease in HHV for the control (HTC-C_HC) and hydrochar after P leaching (HTC-PL_HC). The HHV declined around $11 \%$ from $12.7 \mathrm{MJ} / \mathrm{kg}$ (DSS) to $11.3 \mathrm{MJ} / \mathrm{kg}$ (HTC-C_HC and HTC-PL_HC), which is comparable to reported heating values of other studies with DSS $[8,14]$. After P stripping the hydrochar (HTC-PS_HC) showed with $13.3 \mathrm{MJ} / \mathrm{kg}$ a slight increase of $4.5 \%$ compared to the starting material and was in average $17.7 \%$ above the HHV of HTC-C_HC and HTC-PL_HC.

Table 1. Ultimate analysis and higher heating values (HHV) of digested sewage sludge (DSS) and its derived hydrochars $(\mathrm{HTC}-\mathrm{xx}) .(\mathrm{C}=\mathrm{Control} ; \mathrm{PS}=\mathrm{P}$ stripping; $\mathrm{PL}=\mathrm{P}$ leaching; $\mathrm{HC}=$ Hydrochar $)(n=$ 2).

\begin{tabular}{|c|c|c|c|c|c|c|c|c|c|}
\hline & $\begin{array}{c}\mathrm{C} \\
\text { [wt.\%] }\end{array}$ & $\begin{array}{c}\mathbf{H} \\
{[w t . \%]}\end{array}$ & $\begin{array}{c}\mathrm{N} \\
\text { [wt.\%] }\end{array}$ & $\begin{array}{c}S \\
\text { [wt.\%] }\end{array}$ & $\begin{array}{c}\mathrm{O}_{\mathrm{diff}} \\
{[w \mathrm{w} . \%]}\end{array}$ & $\begin{array}{c}\text { Ash } \\
{[w t . \%]}\end{array}$ & $\mathrm{H} / \mathrm{C}$ & $\mathrm{O} / \mathrm{C}$ & $\begin{array}{l}\text { HHV } \\
\text { MJ/kg }\end{array}$ \\
\hline DSS & 30.2 & 4.4 & 4.2 & 1.0 & 17.3 & 42.8 & 1.7 & 0.4 & 12.7 \\
\hline HTC-C_HC & 27.4 & 3.5 & 2.4 & 0.9 & 10.1 & 55.6 & 1.5 & 0.3 & 11.3 \\
\hline HTC-PS_HC & 30.8 & 3.9 & 3.1 & 8.7 & 8.4 & 45.1 & 1.5 & 0.2 & 13.3 \\
\hline HTC-PL_HC & 27.0 & 3.7 & 2.7 & 9.2 & 9.6 & 47.7 & 1.6 & 0.3 & 11.3 \\
\hline
\end{tabular}

Table 1 summarizes the results from ultimate analyses, as well as gross calorific values on raw material and hydrochar samples. The ash content of the hydrochars decreased by $10 \%$ after the acid treatment, with a minimum ash content of $45.1 \%$ after P stripping. Volumetric carbon dioxide and sulfur dioxide emissions $\mathrm{c}$ are shown in Figure 2. Hydrochars after acid addition show an increase in sulfur content by 9-10 times, which has a direct influence on the $\mathrm{SO}_{2}$ emissions. Hydrochars from HTC-PS and HTC-PL contained more than 6 wt.\% sulfur which, according to the Swiss Clean Air Act (LRV, Annex 5 Number 2), is $3 \%$ above the recommended value for coal, coal briquettes and cokes [39]. The carbon content of the chars as well as the $\mathrm{CO}_{2}$ emissions are very stable and did not show any major changes (Table 1, Figure 2). 


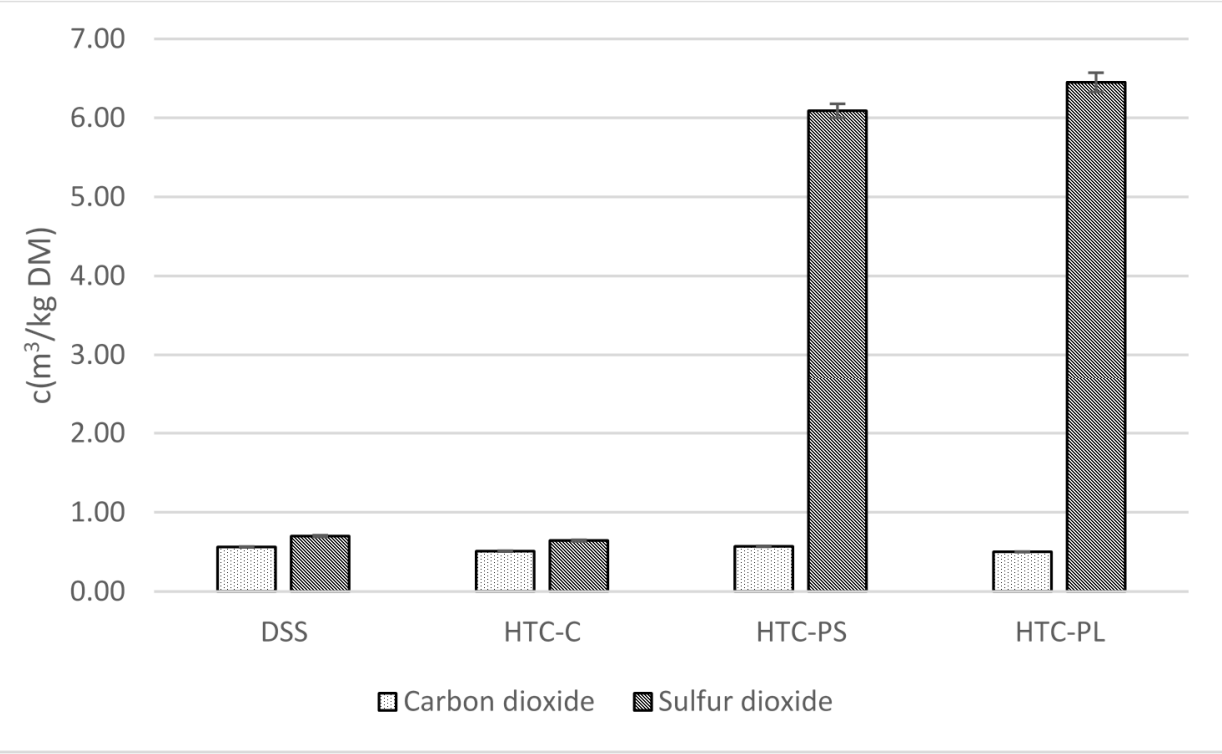

Figure 2. Volumetric carbon dioxide and sulfur dioxide emission per kg dry matter (DM) (Error bars show standard deviation of $n=2$ ).

\subsection{Nutrient Recovery}

The aim of this study was to recover $\mathrm{P}$ and $\mathrm{N}$ from sewage sludge into the process water with minimal heavy metal contamination. Figure 3 shows the recovery of nutrients to the liquid phase. PS achieved with $84 \%$ a $13 \%$ higher P recovery than PL. The difference between the two methods in N recovery is even greater, because for PL it is divided into two liquid fractions. N recovery efficiencies of 53\% for PS_PW and 22\% for PL_Ext were reached. While for PL $32 \%$ of N were in the PW fraction. Compared to the control with $49 \% \mathrm{~N}$ recovery, even without additional treatment considerable amount of $\mathrm{N}$ could be recovered directly into the PW.

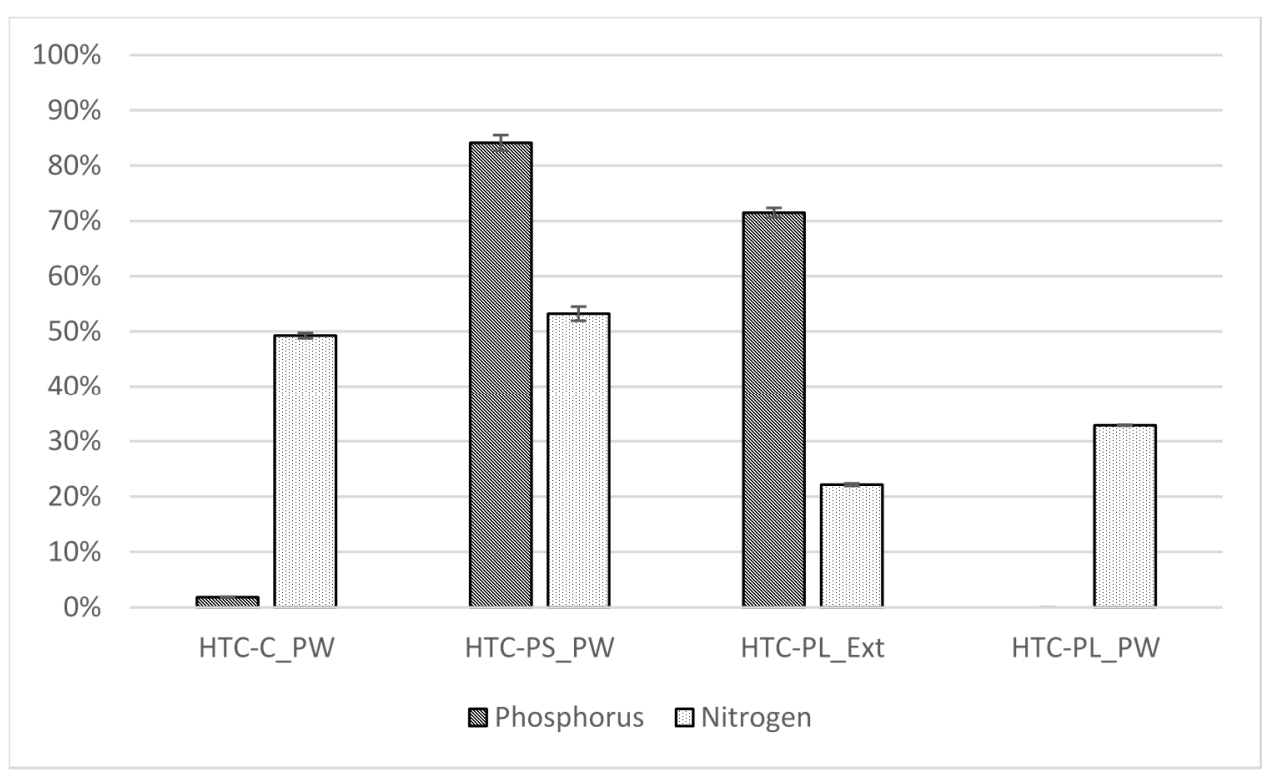

Figure 3. Recovery of main nutrients in the process water (PW) and leaching extract (Ext) (Error bars show standard deviation of $n=2$ ).

Tables 2 and 3 show the nutrient and heavy metal contents in the raw material, hydrochars and liquid phase. Regarding heavy metal contaminations in the liquid phase, only cadmium and zinc could be detected and quantified. The appearance of $\mathrm{Cd}$ could 
not be explained by the authors, as it was not found in the raw material and must have accumulated in the PW. A release of Zn was also observed by Becker et al. [22]. Elemental analysis confirmed that most HM stayed in the hydrochar. An explanation for the high selectivity is the sorption property of the char [22] and the reduction of HM solubility after the HTC-treatment [40].

Table 2. Content analysis of raw material and hydrochars $(\mathrm{HC}) .(\mathrm{C}=\mathrm{Control} ; \mathrm{PS}=\mathrm{P}$ stripping; $\mathrm{PL}=\mathrm{P}$ leaching; $\mathrm{BLD}=$ bellow limit of detection) $(n=2)$.

\begin{tabular}{|c|c|c|c|c|c|c|c|c|}
\hline & \multicolumn{2}{|c|}{ Nutrient Content } & \multicolumn{6}{|c|}{ Heavy Metal Content } \\
\hline & $\mathrm{P}\left[\mathrm{mg} \mathrm{kg}^{-1}\right]$ & N [wt.\%] & $\mathrm{Pb}$ [mg kg $\left.{ }^{-1}\right]$ & $\mathrm{Cd}\left[\mathrm{mg} \mathrm{kg}^{-1}\right]$ & $\mathrm{Cu}\left[\mathrm{mg} \mathrm{kg}^{-1}\right]$ & $\mathrm{Ni}\left[\mathrm{mg} \mathrm{kg}^{-1}\right.$ ] & $\mathrm{Zn}\left[\mathrm{mg} \mathrm{kg}^{-1}\right]$ & $\mathrm{Hg}\left[\mathrm{mg} \mathrm{kg}^{-1}\right]$ \\
\hline DSS & 34,128 & 4.2 & 24.3 & BLD & 262.8 & 21.9 & 700.8 & 0.9 \\
\hline HTC-C_HC & 49,505 * & 2.4 & 20.8 & BLD & 337.5 & 33.2 & 900.5 & 0.5 \\
\hline HTC-PS_HC & $9100 *$ & 3.0 & 39.0 & BLD & 433.5 & 38.9 & 1031.9 & 1.0 \\
\hline HTC-PL_HC & $14,745 *$ & 2.7 & 25.9 & BLD & 367.8 & 43.5 & 894.0 & 1.0 \\
\hline
\end{tabular}

Table 3. Content analysis of process water $(\mathrm{PW})$ and leaching extract $(\mathrm{Ext}) .(\mathrm{C}=\mathrm{Control} ; \mathrm{PS}=\mathrm{P}$ stripping; $\mathrm{PL}=\mathrm{P}$ leaching; $\mathrm{BLD}=$ bellow limit of detection) $(n=2)$.

\begin{tabular}{|c|c|c|c|c|c|c|c|c|c|}
\hline & \multicolumn{2}{|c|}{ Nutrient Content } & \multicolumn{6}{|c|}{ Heavy Metal Content } & \multirow[t]{2}{*}{$\mathrm{pH}$} \\
\hline & $\mathrm{P}\left[\mathrm{mg} \mathrm{L}^{-1}\right]$ & $\mathbf{N}\left[\mathrm{mg} \mathrm{L}^{-1}\right]$ & $\mathrm{Pb}\left[\mathrm{mg} \mathrm{L}^{-1}\right]$ & $\mathrm{Cd}\left[\mathrm{mg} \mathrm{L}^{-1}\right]$ & $\mathrm{Cu}\left[\mathrm{mg} \mathrm{L}^{-1}\right]$ & $\mathrm{Ni}\left[\mathrm{mg} \mathrm{L}^{-1}\right]$ & $\mathrm{Zn}\left[\mathrm{mg} \mathrm{L}^{-1}\right]$ & $\mathrm{Hg}\left[\mathrm{mg} \mathrm{L}^{-1}\right]$ & \\
\hline HTC-C_PW & 208 & 6900 & BLD & BLD & BLD & BLD & BLD & BLD & 7.1 \\
\hline HTC-PS PW & 8113 & 6386 & BLD & BLD & BLD & BLD & 21.3 & BLD & 2.1 \\
\hline HTC-PL_Ext & 16,050 & 6195 & BLD & 0.9 & BLD & BLD & 42.9 & BLD & 2.0 \\
\hline HTC-PL_PW & BLD & 6960 & BLD & BLD & BLD & BLD & BLD & BLD & 7.3 \\
\hline
\end{tabular}

Because of high sulfur and heavy metal content in the hydrochar, it can only be used for energy production in industrial-scale plants (e.g., cement industry, coal-fired power plant, mono-incineration) with appropriate fume cleaning systems. To decrease the sulfur content in the char, sulfuric acid could be substituted with nitric or organic acids (e.g., citric acid) for the P-recovery treatment. However, other mineral and organic acids can increase the leaching costs [22].

While the $\mathrm{N}$ concentrations were for all four liquid samples (PW and Ext) in a similar range (6195-6960 mg N/L), differences in P concentration could be observed. The PW after acid stripping contained $8113 \mathrm{mg} \mathrm{P} / \mathrm{L}$, whereas the highest $\mathrm{P}$ concentration was achieved in the leachate extract (HTC-PL_Ext) with 16,050 $\mathrm{mg}$ P/L. The acid consumption was for both methods (HTC-PS and HTC-PL) at around $14.2 \mathrm{~kg}( \pm 0.3 \mathrm{~kg}) \mathrm{H}_{2} \mathrm{SO}_{4}$ per $\mathrm{kg} \mathrm{P}$.

\subsection{Feasability of Application}

Figure 4 shows hydrochar dewaterability and yield, as well as energy efficiency. Normally, sewage sludge is difficult to separate to a high DM content, because of the microbial cell membranes strongly bound to water [41]. With conventional technologies like a decanter centrifuge or filter press, which are used in WWTPs, a DM content of 20-35\% or $28-45 \%$, respectively, can be obtained [42]. After HTC it was observed that the solid phase settles very quickly and with simple vacuum filtration a DM content of around $40 \%$ could be achieved. This is consistent with other findings, showing the positive effect on the dewaterability of biomass and sewage sludge $[18,43]$. The acid leaching treatment even increased the dewaterability slightly by $6 \%$. All treatments included a single liquid-solid separation by vacuum filtration. It is assumed that the decantation, as an intermediate separation step, had no impact on the dewaterability of PL, as the process water was not removed completely. According to Chen et al. [44], an increase in acidity can improve the dewaterability of activated sludge. This would also explain the improvement in the PL treatment. 


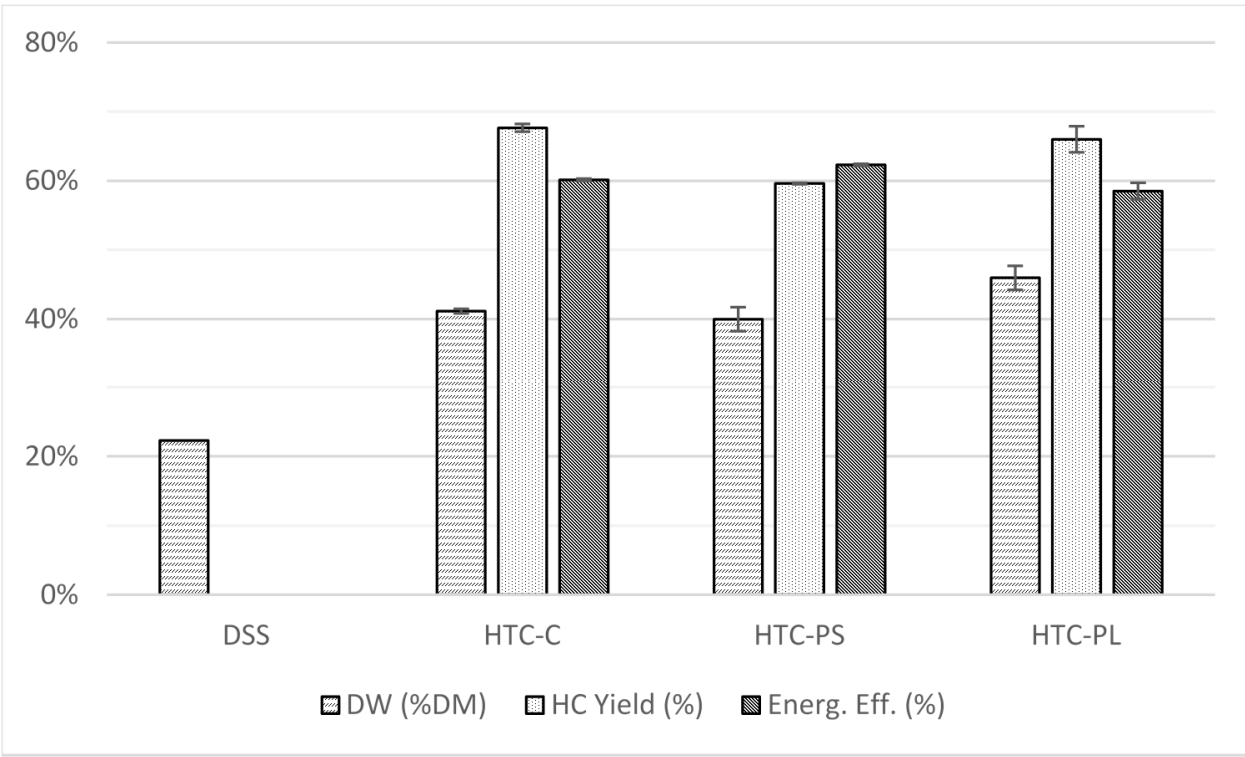

Figure 4. Dewaterability (DW), hydrochar (HC) yield and energy efficiency of the raw material (DSS as received), the control and acid treated hydrochars (Error bars show standard deviation of $n=2$ ).

\subsection{Profitability}

Calculations for annual fixed costs are presented in Table 4 . The specific costs per ton DSS for the HTC treatment depend on the DM content of the delivered sludge and can range between 91 USD and 183 USD with 15\% and 30\% DM content, respectively. On a dry basis, the specific overall costs are 608 USD per ton DM. In Switzerland average disposal costs (incl. transportation) per dry ton sewage sludge amounted in 2001 to: (i) 827 USD for sewage sludge incineration plant; (ii) 882 USD for municipal solid waste incineration plant; and (iii) 669 USD for cement plant (including drying) [45]. The WWTP Werdhölzli in Zurich is one of the biggest WWTPs in Switzerland and operates its own sludge incinerator. The sludge capacity of the plant is designed so that external WWTPs can also deliver their sewage sludge for disposal. The disposal of sludge at the WWTP Werdhölzli costs currently 1173 USD per dry ton [46]. Besides the disposal costs, by 2026 the acid treatment will be an important cost factor for WWTPs. In the current study the acid usage per dry ton DSS was for PS $406 \mathrm{~kg}$ and for PL $349 \mathrm{~kg}$, which adds additional costs of 111 USD and 96 USD per dry ton DSS, respectively. Based on the acid usage per $\mathrm{kg} P$ recovered, both methods are equal with acid costs of 3.96 USD per $\mathrm{kg} P$.

Table 4. Calculation of net costs for the HTC process from GRegio Energie AG (amortization time 10 years, interest rate $2 \%$; $d b=$ dry basis; DSS = digested sewage sludge).

\begin{tabular}{lcc}
\hline \multirow{2}{*}{ Annual Throughput of DSS } & Tons (15\%DM) & $\mathbf{1 1 , 2 0 0}$ \\
\cline { 2 - 3 } & Tons (db) & $\mathbf{1 6 8 0}$ \\
\hline Investment costs & USD & $\mathbf{4 , 3 3 2 , 4 6 0 . 0 0}$ \\
Annual fixed costs & USD /a & $\mathbf{1 , 0 2 2 , 6 7 4 . 0 0}$ \\
Capital costs & USD /a & $482,317.00$ \\
Operation costs & USD /a & $540,357.00$ \\
Electrical energy & USD /a & $88,704.00$ \\
Heat energy & USD /a & $72,441.00$ \\
Rent & USD /a & $74,250.00$ \\
Labor costs & 1 Person (USD) & $110,000.00$ \\
Maintenance & $2.5 \%$ of Invest. (USD) & $108,312.00$ \\
Provision & $1 \%$ of Invest. (USD) & $43,325.00$ \\
Contingency insurance & 1\% of Invest. (USD) & $43,325.00$ \\
Specific overall costs & USD per ton DSS (db) & $\mathbf{6 0 8 . 0 0}$ \\
\hline
\end{tabular}




\section{Conclusions}

Two methods for the nutrient recovery and fuel production were evaluated. For the treatments PS and PL the acid consumption per $\mathrm{kg} P$ recovered were, at around 14.2 $\mathrm{kg}( \pm 0.3 \mathrm{~kg}) \mathrm{H}_{2} \mathrm{SO}_{4}$, equal, whereas for PL an advantage was the reduction of acidified $\mathrm{PW}$ and doubling the P-concentration in the extract. The additional treatment step with sedimentation and decantation and the reduced P-recovery efficiency compared to PS are the only drawbacks of this treatment. In comparison, PS produced a char with a slightly higher HHV, which could be favorable as a fuel substitute for industrial-scale plants. Both treatments exceed the regulatory requirements for $P$ recovery and additionally transfer around $50 \%$ of $\mathrm{N}$ into the liquid phase, while leaving the main part of heavy metals in the hydrochar. A reduction in char-N content improves as well the combustion emissions regarding $\mathrm{NO}_{\mathrm{x}}$. Regarding the high char-S content, only industrial plants with appropriate exhaust gas treatments are applicable. Therefore, sewage sludge will be still available as a climate-neutral fuel for the cement industry and coal power plants.

HTC can compete with current costs for sewage sludge disposal and offers an advantageous alternative to mono-incineration as a sludge treatment, regarding fuel and nutrient recovery. For an implementation in current WWTP infrastructures plants with AD are favored because of their sludge property and the possibility of PW fermentation for higher methane recovery. To promote the P recovery from waste streams like sewage sludge, further investigations in a sustainable and economically feasible fertilizer production are needed.

Author Contributions: Conceptualization, G.G. and L.M.; methodology, G.G.; validation, G.G. and T.K.; formal analysis, G.G., L.M. and T.K.; investigation, G.G., L.M., R.W. and T.K.; resources, G.G., L.M., R.W. and T.K.; data curation, G.G. and L.M.; writing-original draft preparation, G.G.; writing - review and editing, G.G. and R.K.; visualization, G.G.; supervision, G.G. and R.K.; project administration, G.G.; funding acquisition, G.G. All authors have read and agreed to the published version of the manuscript.

Funding: This research was funded by cemsuisse, the Association of the Swiss Cement Industry. The article processing charges for the open access publication was funded by ZHAW Zurich University of Applied Sciences.

Institutional Review Board Statement: Not applicable.

Informed Consent Statement: Not applicable.

Data Availability Statement: Not applicable.

Acknowledgments: The authors would like to thank for the financial support received from cemsuisse, the Association of the Swiss Cement Industry and ZHAW Zurich University of Applied Sciences for funding the open access publication. The authors would also like to thank Samuel Solin and Simon Kaiser, Institute of Bioenergy and Resource Efficiency at the FHNW University of Applied Sciences and Arts Northwestern Switzerland, for the help with the elemental analysis.

Conflicts of Interest: The authors declare no conflict of interest. The funders had no role in the design of the study; in the collection, analyses, or interpretation of data; in the writing of the manuscript. The project funders agreed to publish the results.

\section{References}

1. Mathieux, F.; Ardente, F.; Bobba, S.; Nuss, P.; Blengini, G.; Alves Dias, P.; Blagoeva, D.; Torres De Matos, C.; Wittmer, D.; Pavel, C.; et al. Critical Raw Materials and the Circular Economy—Background Report; Publications Office of the European Union: Luxembourg, 2017.

2. European Commission. Communication from the Commission to the European Parliament, the Council, the European Economic and Social Committee and the Committee of the Regions; On the Review of the List of Critical Raw Materials for the EU and the Implementation of the Raw Materials Initiative; European Commission: Brussels, Belgium, 2014.

3. Binder, C.R.; de Baan, L.; Wittmer, D. Phosphorflüsse in Der Schweiz. Stand, Risiken Und Handlungsoptionen; Umwelt-Wissen; Bundesamt für Umwelt: Bern, Switzerland, 2009; p. 161.

4. Daneshgar, S.; Callegari, A.; Capodaglio, A.; Vaccari, D. The Potential Phosphorus Crisis: Resource Conservation and Possible Escape Technologies: A Review. Resources 2018, 7, 37. [CrossRef] 
5. Cordell, D.; White, S. Life's Bottleneck: Sustaining the World's Phosphorus for a Food Secure Future. Annu. Rev. Environ. Resour. 2014, 39, 161-188. [CrossRef]

6. Hermann, L. Rückgewinnung von Phosphor aus der Abwassereinigung; Umwelt-Wissen; Bundesamt für Umwelt: Bern, Switzerland, 2009; p. 196.

7. Bigalke, M.; Ulrich, A.; Rehmus, A.; Keller, A. Accumulation of Cadmium and Uranium in Arable Soils in Switzerland. Environ. Pollut. 2017, 221, 85-93. [CrossRef] [PubMed]

8. Bigalke, M.; Schwab, L.; Rehmus, A.; Tondo, P.; Flisch, M. Uranium in Agricultural Soils and Drinking Water Wells on the Swiss Plateau. Environ. Pollut. 2018, 233, 943-951. [CrossRef]

9. Bigalke, M.; Imseng, M.; Schneider, S.; Schwab, L.; Wiggenhauser, M.; Keller, A.; Müller, M.; Frossard, E.; Wilcke, W. Uranium Budget and Leaching in Swiss Agricultural Systems. Front. Environ. Sci. 2020, 8, 54. [CrossRef]

10. Schnug, E.; Haneklaus, N. Uranium in phosphate fertilizers-Review and outlook. In Uranium-Past and Future Challenges; Merkel, B.J., Arab, A., Eds.; Springer International Publishing: Cham, Germany, 2015; pp. 123-130. ISBN 978-3-319-11058-5.

11. Tulsidas, H.; Gabriel, S.; Kiegiel, K.; Haneklaus, N. Uranium Resources in EU Phosphate Rock Imports. Resour. Policy 2019, 61, 151-156. [CrossRef]

12. Roth, N.; FitzGerald, R. Human and Environmental Impact of Uranium Derived from Mineral Phosphate Fertilizers; Swiss Centre for Applied Human Toxicology: Basel, Switzerland, 2015; p. 50.

13. Nutrient Source Specifics-Ammonia. Available online: www.ipni.net/specifics (accessed on 19 April 2021).

14. Kyriakou, V.; Garagounis, I.; Vourros, A.; Vasileiou, E.; Stoukides, M. An Electrochemical Haber-Bosch Process. Joule 2020, 4 , 142-158. [CrossRef]

15. Krämer, J. Phosphorrecycling: Wer, Wie, Was?-Umsetzung Einer Iterativen, Zielgruppenorientierten Kommunikationsstrategie; Deutsche Phosphor Plattform: Frankfurt, Germany, 2019; p. 108.

16. Libra, J.A.; Ro, K.S.; Kammann, C.; Funke, A.; Berge, N.D.; Neubauer, Y.; Titirici, M.-M.; Fühner, C.; Bens, O.; Kern, J.; et al. Hydrothermal Carbonization of Biomass Residuals: A Comparative Review of the Chemistry, Processes and Applications of Wet and Dry Pyrolysis. Biofuels 2011, 2, 71-106. [CrossRef]

17. Zhao, P.; Chen, H.; Ge, S.; Yoshikawa, K. Effect of the Hydrothermal Pretreatment for the Reduction of NO Emission from Sewage Sludge Combustion. Appl. Energy 2013, 111, 199-205. [CrossRef]

18. Escala, M.; Zumbühl, T.; Koller, C.; Junge, R.; Krebs, R. Hydrothermal Carbonization as an Energy-Efficient Alternative to Established Drying Technologies for Sewage Sludge: A Feasibility Study on a Laboratory Scale. Energy Fuels 2013, 27, 454-460. [CrossRef]

19. Ahmed, M.; Andreottola, G.; Elagroudy, S.; Negm, M.S.; Fiori, L. Coupling Hydrothermal Carbonization and Anaerobic Digestion for Sewage Digestate Management: Influence of Hydrothermal Treatment Time on Dewaterability and Bio-Methane Production. J. Environ. Manag. 2021, 281, 111910. [CrossRef] [PubMed]

20. Marin-Batista, J.D.; Mohedano, A.F.; Rodríguez, J.J.; de la Rubia, M.A. Energy and Phosphorous Recovery through Hydrothermal Carbonization of Digested Sewage Sludge. Waste Manag. 2020, 105, 566-574. [CrossRef]

21. Maurizio, V.; Luca, F.; Fabio, M.; Antonio, M. Andreottola Gianni Hydrothermal Carbonization as an Efficient Tool for Sewage Sludge Valorization and Phosphorous Recovery. Chem. Eng. Trans. 2020, 80, 199-204. [CrossRef]

22. Becker, G.C.; Wüst, D.; Köhler, H.; Lautenbach, A.; Kruse, A. Novel Approach of Phosphate-Reclamation as Struvite from Sewage Sludge by Utilising Hydrothermal Carbonization. J. Environ. Manag. 2019, 238, 119-125. [CrossRef]

23. Egle, L.; Rechberger, H.; Zessner, M. Phosphorrückgewinnung aus dem Abwasser; Bundesministerium für Land- und Forstwirtschaft, Umwelt und Wasserwirtschaft, Sektion VIIWasser: Vienna, Austria, 2014; p. 323.

24. Fux, C.; Theiler, M.; Irzan, T. Studie Phosphorrückgewinnung aus Abwasser und Klärschlamm; TBF+Partner AG: Zürich, Switzerland, 2015; p. 92.

25. Blöhse, D. Anaerobe Verwertung von HTC-Prozesswässern. In Proceedings of the Biokohle im Blick—Herstellung, Einsatz und Bewertung, 73. Symposium des ANS e.V., Berlin, Germany, 20 September 2012.

26. Ferrentino, R.; Merzari, F.; Fiori, L.; Andreottola, G. Coupling Hydrothermal Carbonization with Anaerobic Digestion for Sewage Sludge Treatment: Influence of HTC Liquor and Hydrochar on Biomethane Production. Energies 2020, 13, 6262. [CrossRef]

27. Zhao, K.; Li, Y.; Zhou, Y.; Guo, W.; Jiang, H.; Xu, Q. Characterization of Hydrothermal Carbonization Products (Hydrochars and Spent Liquor) and Their Biomethane Production Performance. Bioresour. Technol. 2018, 267, 9-16. [CrossRef] [PubMed]

28. Parmar, K.R.; Ross, A.B. Integration of Hydrothermal Carbonisation with Anaerobic Digestion; Opportunities for Valorisation of Digestate. Energies 2019, 12, 1586. [CrossRef]

29. Aragón-Briceño, C.; Ross, A.B.; Camargo-Valero, M.A. Evaluation and Comparison of Product Yields and Bio-Methane Potential in Sewage Digestate Following Hydrothermal Treatment. Appl. Energy 2017, 208, 1357-1369. [CrossRef]

30. Merzari, F.; Langone, M.; Andreottola, G.; Fiori, L. Methane Production from Process Water of Sewage Sludge Hydrothermal Carbonization. A Review. Valorising Sludge through Hydrothermal Carbonization. Crit. Rev. Environ. Sci. Technol. 2019, 49, 947-988. [CrossRef]

31. Shi, Y.; Luo, G.; Rao, Y.; Chen, H.; Zhang, S. Hydrothermal Conversion of Dewatered Sewage Sludge: Focusing on the Transformation Mechanism and Recovery of Phosphorus. Chemosphere 2019, 228, 619-628. [CrossRef]

32. Aragón-Briceño, C.I.; Pozarlik, A.K.; Bramer, E.A.; Niedzwiecki, L.; Pawlak-Kruczek, H.; Brem, G. Hydrothermal Carbonization of Wet Biomass from Nitrogen and Phosphorus Approach: A Review. Renew. Energy 2021, 171, 401-415. [CrossRef] 
33. Biswas, B.K.; Inoue, K.; Harada, H.; Ohto, K.; Kawakita, H. Leaching of Phosphorus from Incinerated Sewage Sludge Ash by Means of Acid Extraction Followed by Adsorption on Orange Waste Gel. J. Environ. Sci. 2009, 21, 1753-1760. [CrossRef]

34. BBodSch, V. Federal Soil Protection and Contaminated Sites Ordinance; German Federal Council: Berlin, Germany, $1999 ;$ p. 1554.

35. Kaltschmitt, M.; Hartmann, H.; Hofbauer, H. (Eds.) Energie aus Biomasse: Grundlagen, Techniken und Verfahren; Springer: Berlin/Heidelberg, Germany, 2016; ISBN 978-3-662-47438-9.

36. Gao, Y.; Yu, B.; Wu, K.; Yuan, Q.; Wang, X.; Chen, H. Physicochemical, Pyrolytic, and Combustion Characteristics of Hydrochar Obtained by Hydrothermal Carbonization of Biomass. BioResources 2016, 11, 4113-4133. [CrossRef]

37. Li, Z.; Yi, W.; Li, Z.; Tian, C.; Fu, P.; Zhang, Y.; Zhou, L.; Teng, J. Preparation of Solid Fuel Hydrochar over Hydrothermal Carbonization of Red Jujube Branch. Energies 2020, 13, 480. [CrossRef]

38. Lucian, M.; Fiori, L. Hydrothermal Carbonization of Waste Biomass: Process Design, Modeling, Energy Efficiency and Cost Analysis. Energies 2017, 10, 211. [CrossRef]

39. Luftreinhalte-Verordnung; Swiss Federal Council: Bern, Switzerland, 1985; (Status as of 1 April 2020); p. 82.

40. Liu, M.; Duan, Y.; Bikane, K.; Zhao, L. The Migration and Transformation of Heavy Metals in Sewage Sludge during Hydrothermal Carbonization Combined with Combustion. BioMed Res. Int. 2018, 2018, 1913848. [CrossRef]

41. Wei, H.; Gao, B.; Ren, J.; Li, A.; Yang, H. Coagulation/Flocculation in Dewatering of Sludge: A Review. Water Res. 2018, 143, 608-631. [CrossRef]

42. Böhler, M.; Siegrist, H.; Pinnow, D.; Müller, D.; Krauss, W.; Brauchli, H. Neue Presstechnologie zur verbesserten Klärschlammentwässerung; EAWAG: Dübendorf, Switzerlnd, 2003; p. 42.

43. Funke, A.; Ziegler, F. Hydrothermal Carbonization of Biomass: A Summary and Discussion of Chemical Mechanisms for Process Engineering. Biofuels Bioprod. Biorefin. 2010, 4, 160-177. [CrossRef]

44. Chen, Y.; Yang, H.; Gu, G. Effect of Acid and Surfactant Treatment on Activated Sludge Dewatering and Settling. Water Res. 2001, 35, 2615-2620. [CrossRef]

45. Laube, A.; Vonplon, A. Klärschlammentsorgung in Der Schweiz-Mengen- Und Kapazitätserhebung; Umwelt-Materialien; BUWAL: Bern, Switzerland, 2004; p. 47.

46. Schlamm Aus Klärwerken—Preise Für Die Anlieferung von Schlamm Aus Klärwerken. Available online: www.stadt-zuerich.ch/ ted/de/index/entsorgung_recycling/sauberes_wasser/entsorgen/schlamm_aus_klaerwerken.html (accessed on 21 January 2021). 